\title{
High-Achieving Students' Strategies toward E-Learning Practice during Covid-19 Pandemic
}

\author{
Hujah Tu'al' Syadiah \\ IAIN Bengkulu \\ hujahtual@gmail.com \\ Andri Saputra \\ IAIN Bengkulu \\ Andri.saputraozz@gmail.com \\ Ali Akbarjono \\ IAIN Bengkulu \\ Aliakbarj250975@gmail.com
}

\begin{abstract}
This research investigates the strategies used by high-achieving students of the English department at several colleges and their understanding of learning materials studied during the Covid-19 Pandemic. The researcher decided on a small sample size of 9 students majoring in English at several universities in Bengkulu to be sampled in this research, ranging in age 20 to 21 years old. This research employed a descriptive qualitative method to collect the research data using the interview method to answer the research questions. After the interview, the data obtained will be transcribed. After transcribing the data then the data is coded and categorized using thematic data analysis. Thematic analysis is one method of analyzing data to establish trends or to discover subjects in the data gathered by the researcher. This method is very effective. Here are the stages of doing data analysis using the thematic analysis approach in more depth: a) Familiarisation with the data, b) coding data, c) Findings themes, and d) Reviewing theme. From the results of this study, following the focus of the proposed research, there are three kinds of strategies used by nine students in this study. The first is a note-taking strategy, the second is a reading strategy, and the third is a recording strategy. This strategy is used by students who high-achieving in the learning process to understand the material being studied.
\end{abstract}

Keywords: Students' Strategies, E-Learning

\section{A. Introduction}

This research attempts to investigate the strategies used by high-achieving students of the English department at several colleges and their understanding of learning materials studied during the Covid-19 Pandemic. It is generally acknowledged that the Covid-19 is a highly infectious disease or illness caused by severe acute respiratory syndrome coronavirus 2, originated in Wuhan city of China, and it has already taken on pandemic proportions, affecting across all the continents.

Since the covid-19 virus outbreak, learning in Indonesia has been carried out into distance learning to prevent the spread of the covid-19 virus. Nadiem Anwar Makarim, 
Minister of Education and Culture, released circular Number 4 of 2020 concerning the Implementation of Education in a Coronavirus (Covid-19) Emergency (Kemendikbud, 2020).

Moreover, distance learning seems to be an alternative currently used by every school and university to carry out the teaching and learning process, even though it is not face-to-face. This distance learning becomes a challenge for every teacher and student. In learning that is carried out online, it has several difficulties such as difficulties in networking, difficulties in internet packages, and difficulties in implementing learning steps (Alchamdani, 2020).

Changes in the learning system from previously face-to-face to online certainly have an impact on the learning strategies used (Lalu, 2020). Online learning urgently requires various strategies to draw learning approaches to online learners or strategies for effective online and distance learning. A decent learning strategy requires strengthening the interaction between students and teachers because this pandemic distance makes the relationship between the two virally important.

Learning strategies are specific actions taken by the learner to make learning easier, faster, more enjoyable, self-directed, more effective, and transferrable to new situations. As Oxford explained, learning strategies: 1) contribute to the main goal that is communicative competence, 2) allow the learner to become more self-directed, 3) expand the role of teachers, 4) are problem-oriented, 5) are specific actions taken by the learner, 6) involve many aspects of the learner, not just the cognitive, 7) support learning both directly and indirectly, 8) are not always observable, 9) are often conscious, 10) can be taught 11) are flexible and 12) are influenced by a variety of factors (Oxford,1990).

Changes in the learning system from previously face-to-face to online certainly impact the learning strategies used (Alchamdani, 2020). Based on the researcher's experience, studying during the Covid-19 pandemic is deemed challenging - I have to have a good strategy in terms of online learning.

Furthermore, based on interviews with one of the universities, namely several 6thsemester students of IAIN Bengkulu, Thursday, March 11, 2021. Data collection was carried out from the results of interviews. In the learning process during the Covid-19 period, they claimed that they had experienced difficulties with the current learning system; this was due to the less conducive learning facilities. This shows that there are still students who are late entering class when learning begins. As well as the lack of strategies they used during 
learning and made them not optimal in achieving these learning objectives, some students did not have an appropriate strategy to use during the learning process. Furthermore, they stated that they had difficulties learning online during the pandemic, especially with unsupported internet signals and limited learning media.

Learning strategies that will be applied by students, of course, each one has a specific purpose. Understanding the strategy itself is an attempt to gain success and success in accomplish achievements. Strategy can be interpreted as planning contains a series of activities designed to achieve goals education. The learning strategy of students is a series of activities learning carried out by students in order to achieve goals learn it.

Derived from the exceeding, the researcher focuses on investigating learning strategies used by high-achieving students of the English department at several colleges during the Covid-19 pandemic and their understanding of learning materials studied during the Covid-19 Pandemic. By all the explanation above the researcher decides to conduct the research entitled 'High-Achieving Students' Strategies towards E-Learning Practice during Covid-19 Pandemic (A Descriptive Qualitative Study at EFL students of IAIN Bengkulu, $U M B$, and $U N I B)$.

\section{B. Research Methodology}

This research employed a descriptive qualitative method to collect the research data using the interview method to answer the research questions. Research interviews are more than just conversational and range from informal to formal. However, all conversations have specific rules of transfer of control by one or the other participant. Unlike in casual conversation, research interviews aim to obtain information from one side only; therefore, asymmetrical relationships must be apparent.

According to Sugiyono, Qualitative methods are used to obtain in-depth data that contains meaning (Sugiyono, 2012). Furthermore, qualitative is a study aimed at describing and analyzing a phenomenon, event, social activity, manner, perception of each individual or in a particular group (Ariesto Hadi, 2010). Qualitative research entails the use of collected data to identify, explain, and analyze it.

From some of the explanations above, it can be concluded that qualitative research is a research procedure that prioritizes the description of words. The primary purpose of descriptive research is to describe the state of view as it exists today. Stated, this is a fact- 
finding investigation. In descriptive research, conclusions can indeed be accepted, but it does not build a cause and effect relationship.

To explore the experiences and ideas of the subject, researchers tend to focus on the interview. In this research, the researcher intends to answer the question of the strategies applied by high-achieving students toward E-Learning practice during the Covid-19 pandemic and to what extent do the high-achieving students understand the learning practice during the Covid-19 pandemic.

To answer the two research questions, the researcher decided on a small sample size of 9 students majoring in English at several universities in Bengkulu to be sampled in this research, ranging in age 20 to 21 years old.

Participants in this research would be chosen according to the criterion requested by the interviewer. Therefore, while they will participate voluntarily in this review, they need to follow some criteria if they wish to participate. The criterion referred to are students of highachieving in the English department who have a minimum GPA of 3.50 in semester 6 , to be specific.

After the interview, the data obtained will be transcribed. After transcribing the data then the data is coded and categorized using thematic data analysis. Thematic analysis is one method of analyzing data to establish trends or to discover subjects in the data gathered by the researcher. This method is very effective. However, when a study intends to analyze in detail the qualitative data, they have to find linkage of patterns in a phenomenon and explain the extent to which a phenomenon occurs through the researcher's eyes. Here are the stages of doing data analysis using the thematic analysis approach in more depth: a) Familiarisation with the data, b) coding data, c) Findings themes, and d) Reviewing theme (Heriyanto, 2019).

For the validity of the data, use triangulation. Triangulation is the method of using a particular point of view to validate questions or expand previous results (Phil Tumer, 2020). Triangulation is commonly seen as encouraging a more detailed interpretation of the phenomena under review and enhancing the rigor of a scientific study (Roberta, 2013).

\section{Results and Discussion}

\section{Results}

\section{Learning strategies used by high-achieving English students in E-learning}


The following is an overview of the strategies used by research subjects that reflect their activities in completing their daily learning tasks.

a. Elaboration Strategy

\section{1) Note Strategy}

The note-taking strategy is a strategy that is widely used by students, this is proven based on the results of interviews with 9 students, 6 of 9 students use note-taking strategies in the learning process to recall the material that has been explained. Most of them only note the essential points. Subjects understood all the information they note until they understood what they noted. This is useful when they have difficulty understanding the material they are studying. That way, they will be able to understand the material being studied.I

b. Repeating Strategy

1) Reading Strategy

In addition to the note-taking strategy, students often use the reading strategy, but only 4 out of 9 participants used this reading strategy. They reread the material they have noted. This strategy is done by reading the material that has been studied and has not been studied so that it understands and is easy to understand.

Participants understand all the material they read until they understand what they read. This helps them when they have difficulty understanding the material being studied. That way, they can save it and ask it back to the lecturer concerned, even if they look for references from journals on the internet site or references from YouTube to find information or read the material.

Participants understand all the material they read until they understand what they are reading. This helps them when they have difficulty understanding the material being studied. That way, they can 
save it and ask it back to the lecturer in question. They look for references from journals on the internet site or references from YouTube to find information or read the material.

\section{c. Recording Strategy}

In addition to the note-taking strategy and reading strategy, the recording strategy was also used by the students I interviewed. However, only 1 out of 9 participants applied this strategy. The participant's recording activity was more of an audiovisual. She preferred to watch videos related to the material being studied rather than read the book, especially the book in the form of a PDF file because it made her feel bored.

Based on the interviews' results above, students use three strategies during the learning process. The three strategies are note-taking strategies, reading strategies, and recording strategies.

\section{Understanding of high-achieving students strategies toward E-learning}

To determine how far the achievement students understand, the researchers interviewed all participants about the material they had studied. Of the 9 participants, they were all able to answer all the questions that had been given. Based on the results of the interviews above, their understanding of the material that has been studied is excellent; it can be seen from their ability to answer questions during the interview. Not only that, but this is also evident from the A grades they got in the 5 th semester.

Not only that, in achieving their success while studying, they are also supported by motivational factors that make them have to be able to achieve goals in learning, whether this is during a pandemic or face-to-face

\section{Discussion}

According to Fred Nickols, the word "strategy" refers to a dynamic network of concepts, perspectives, interactions, objectives, skills, memories, beliefs, and desires that provide general direction for specific activities in pursuit of specific goals. The strategy is concerned with how you will achieve your aims, not what those are or ought to be, or how they are established (Fred Nickols, 2016). 
Meanwhile, Nur stated that learning strategies refer to the behavior and thinking processes used by students that affect what is learned, including memory and metacognitive processes. It includes repetition, elaboration, organization and metacognitive strategies (Nur, 2000).

\section{High-achieving student learning strategies}

Student learning strategies are used to achieve a learning goal to be achieved in the learning. Not only that, learning strategies also refer to the behavior and thinking processes used by students that affect what is learned, including memory and metacognitive processes in the realization of teaching and learning activities to achieve the goals that have been set. Learning strategies are basically different for each student, especially for high achieving students. The difference in the implementation of this strategy is of course also influenced by the personal experience of each individual.

If you look more closely, you can see the similarities in the application of the learning strategies of the 9 research subjects. This equation is obtained by looking at the interview data that has been obtained. From the results of this study according to the research focus, there are 3 kinds of strategies used by 9 research subjects. With the following explanation: 6 out of 9 subjects used a note-taking strategy, 4 out of 9 used a reading strategy, and 1 out of 9 subjects used a recording strategy.

Furthermore, Oxford defines learning strategies as behaviors used by learners so that language learning is successful, directed, and enjoyable. These strategies are strategies that students use to solve certain learning problems. For example, students are often given the task of doing learning tasks such as making a summary of a particular material. They will automatically read the material given first and start making summary notes on the material (Oxford, 1990).

Although the successful completion of these tasks is the goal of learning, one essential thing is mastering the learning process itself: choosing an appropriate learning strategy and monitoring the strategy's effectiveness.

\section{Undesrstanding of student achievement learning strategies}

Based on the results of the interview data above, students can understand the material that has been studied, seen from them being able to answer questions during 
interviews. Furthermore, this is reinforced based on the explanation from Thasis, C, and Academic writing is an essential thought of writing that is needed to focus on university. There are many names for academic writing, such as; essays, papers, research papers, etc. The names have the same principle and purpose (Thais, 2006).

Allwright mention that it is a research centers on the classroom, and simply tries to investigate what happens inside the classroom interaction as virtually happens inside the classroom. It treats classroom interaction as virtually the only object worthy of investigation (Allwright, 1991).

A student's understanding of learning in understanding lessons on campus cannot be separated from the factors that influence it. These factors exist from within the students themselves, including learning and their study habits, and even the people's motivational factors. In achieving these learning objectives, students are also active during the learning process, such as asking, answering, and refuting a discussion. The way students learn is one of the critical factors that significantly affect the achievement or understanding of learning obtained.

\section{Conclusion and Suggestion}

\section{Conclusion}

Learning strategy is a learning process used by students to achieve a learning goal. Learning strategies have differences for each student, especially for high achieving students; they have particular strategies in achieving learning goals. When viewed from the study results, there are several similarities in the application of the learning strategies of the nine students in this study.

From the results of this study, following the focus of the proposed research, there are 3 kinds of strategies used by nine students in this study. The first is a notetaking strategy, the second is a reading strategy, and the third is a recording strategy. 
This strategy is used by students who high-achieving in the learning process to understand the material being studied.

\section{Suggestion}

a. Suggestion for teacher

The process of teaching and learning activities is good if there is reciprocity between students and teachers. The application of the teaching pattern provided by the teacher should pay attention to the characteristics possessed by each student so that the learning process itself can provide satisfactory results.

b. Suggestion for students

Study planning is something important for students. Clarity of learning objectives will direct the form of behavior carried out. Therefore, it is essential to make a simple plan to achieve learning objectives. Students can take advantage of various learning strategies; these learning strategies will help students when facing various difficulties in learning. Moreover, it can also improve ability in learning, especially in Learning Strategies. Moreover, for students who do not excel, they must make outstanding students a reference in using strategies in learning to create a sense of achievement for students and create a spirit of competition with other students.

c. Suggestion for future researchers

Given the importance of the processes that occur in learning strategies to improve students' abilities, it is better to sharpen the focus of research to obtain a broader picture between students who use particular strategy and those who do not use unique strategy in learning.

\section{References}

Alchamdani, et al. (2020). The Impact of Covid-19 Pandemic on Online Learning Process in The College at Southest Sulawesi. Surabaya. Faculty of Public Health, Airlangga University. Vol.12 No.1.

Allwright, Dick., Bailey, Kathlen M. (1991). Focus On The Language Classroom An Introduction To Classroom Research For Language Teachers. Cambridge: Cambridge University Press

Atsani \& Zainuddin, L.G.M. (2020). The Transformation of Learning Media During the Covid-19 Pandemic. Lombok Timur. Jurnal Studi Islam. Vol.1 No.1.

Hales, D. (2010). An Introduction to Triangulation. Swees: Unaids Monitoring and Evaluation Division.

Heriyanto. (2019). Thematic Analysis sebagai metode Menganalisa Data untuk Penelitian Kualitatif. Diponegoro: Universitas Diponegoro. 
Kemendikbud. Pelaksanaan Pendidikan dalam Masa Darurat Covid-19. https://www.kemdikbud.go.id/main/blog/2020/03/mendikbudterbitkan-se-tentang pelaksanaan-pendidikan-dalam-masa-darurat-covid19. Accessed on February 06, 2021.

Nickols, F. (2016). Strategy definitions \& Meanings. Accessed on February 06, 2021 by https://www.nickols.us/strategy_definitions.pdf Oxford, R, L. 1990. Language Learning Strategies: What Every Teacher Should Know. New York

Nur, M. (2000). Strategi-strategi belajar. Surabaya: Universitas Negeri Surabaya

Oxford, R, L. (1990). Language Learning Strategies: What Every Teacher Should Know. New York

Sugiyono. (2012). Metode Penelitian Pendidikan Pendekatan Kuantitatif, Kualitatif dan R \& D. Bandung: Alfabeta

Sutopo, A.H. and Adrianus Arief. (2010). Terampil Mengolah Data Kualitatif. Prenada Media Group: Jakarta.

Thaiss, C. \& Zawacki, T. (2006). Engaged Writers, Dynamic Disciplines: Research on the Academic Writing Life. Portsmouth, NH: Boynton/Cook, Heinnemann.

Turner, P. \& Susan, T. (2020). Triangulation in Practice. Inggris: Edinburgh Napier University. 